\title{
Testicular Germ Cell Neoplasia In Situ with Extratubular Extension
}

National Cancer Institute

\section{Source}

National Cancer Institute. Testicular Germ Cell Neoplasia In Situ with Extratubular

Extension. NCl Thesaurus. Code C7326.

A malignant neoplasm that arises from the testis and is characterized by the presence of large germ cells with abundant cytoplasm in the seminiferous tubules, associated with an invasive germ cell tumor in the adjacent tissues. 